\title{
TEN YEARS OF PERFORMANCE BUDGET IMPLEMENTATION IN POLAND - SUCCESSES, FAILURES, FUTURE
}

\author{
MARTA POSTUEA
}

\begin{abstract}
The article presents public governance instruments used to fulfill respective functions of the state. At the same time, attention is drawn to the fact that what matters is not only the instruments but also governance methods in which the same are used, which is why an attempt is made in the article to make reference mainly to the issues related to performance budgeting. However, guidelines on how to improve this tool should not overshadow the main conclusion, namely that citizens can be confident about the quality of tools used in Poland. Consequently, efforts should be made to further improve them, but they should be adapted to the realities of a given country as there is nothing more erroneous than to apply models that, admittedly, work out worldwide but can be in no way incorporated into Polish social systems and into Polish traditions, habits and culture. Furthermore, solutions developed for the purposes of one country may prove not only effective locally, but also usable elsewhere. A good example would be the Polish recipe for maintaining GDP growth rate during the crisis, which Europe can learn from.
\end{abstract}

\section{Keywords}

Performance budget; efficiency; governance; transparency

\section{JEL Classification: H30, H40, H50}

1 Habilitated doctor, associate professor at the University of Warsaw, Faculty of Department, Director of the
Centre for Entrepreneurship, professor at Kozminski University (Poland). The author specializes in government
finance, EU public finance and public debt management. Contact email: mpostula@wz.uw.edu.pl. 


\section{Introduction}

Poland is one of the CEE countries which, for the last 28 years, have been undergoing a quite systematic process of transitioning from centrally-controlled economy to free-market economy. As part of the institutional changes taking place, the economic structure has also been changing, and the social and economic policy has been faced with newer and newer challenges. The recent crisis of 2007-2008 showed that the tools chosen in Poland to stimulate and stabilize the social and economic growth are bringing the expected outcomes. Poland was one of the few EU countries, and of the few countries in general, to record an economic growth of ca. 3\% GDP in the period of 2009-2010. The condition of public finance in the period analyzed was improving quite systematically and the government quite smoothly (and with no negative effect for public finance deficit and for public debt) was implementing consolidation packages which, as proven over time, helped lay the solid foundation for the Polish economy.

Considering the evolution of indicators reflecting the fiscal policy, it is important to establish whether and in what way these were promoted not only by relevant decisions but also by methods of public finance management supporting the decision-making process. Consequently, one of the main goals of the article is to evaluate one of the institutional solutions applied in Poland to ensure efficient, smooth management of public funds that is performance budgeting. Several years into the implementation of this solution, it is worth reflecting on it and drawing conclusions from the measures adopted by the Polish government.

The article presents a comparative analysis of performance budget definitions, and the new trends emerging in the contemporary discourse on public governance methods. The analysis was applied to publications on this topic as part of the purposive sampling of literature. The fundamental differences and similarities between the traditional and performance-based public finance management are discussed. A thought experiment method is also used as part of the iterative process of the analytical method and logical construct. To that end, stress conditions are identified as defined in the performance-based budget development - both in the context of threats and opportunities, by constructing relevant logical sequences between the gaps and possibilities to use correlations presented therein, as part of corrections of the logical process.

\section{Management by Objectives as a Tool Used in Public Sector}

For decades now, experts and economists have been analyzing and debating on the public spending efficiency, especially the efficiency of the distribution role of 
the government. These debates have been conducted both internationally and in Poland. Eminent researchers develop various methods to demonstrate the efficiency of public transfer sector or lack thereof, due to bad governance method or bad choice of instruments used by the public finance sector. In Poland, the discussion on the quality of public transfers, especially of the public spending, has been on for at least several decades now, pointing out, each time, to the ever-topical need to improve the efficiency of public spending both from the state budget and from other entities comprising the public sector. The eternal question that proposes itself is how to measure this efficiency and how to set the yardstick for such efficiency? Should this yardstick be the scale of expenditure transferred to the economy, as this way we can, indirectly, increase consumption and make it grow faster, or directly, stimulate the growth in the desirable direction, which thus reduces the range of poverty or the scale of social exclusion, among others? Or maybe the efficiency of public spending should be measured out in public goods provided, their quality or even by the citizens' satisfaction level?

With dilemmas presented this way, one cannot talk solely about the quality of public goods as the only priority. After all, they are funded from taxes, the amount of which undoubtedly impacts the economic growth, which was discussed more broadly in the first part of the article. What are the tools for measuring this efficiency then? If we take a close look at international solutions, obviously the practice of efficiency measurement is a widely-established phenomenon, and one that is intensely developed as methodological progress is achieved and knowledge in that domain grows. For example, in 2015 (OECD, 2011: 140), OECD formulated the so-called quality-of-life index, which refers to several major elements indicating the role of government, and the indicators of importance for this issue. Such perspective on the issue corresponds to the fundamental dilemma of "what is the government's purpose"?

There is a widely accepted paradigm that the government acts for and for the benefit of citizens, in order to, among other things, balance social differences, eliminate poverty, satisfy the basic needs of the citizens who live on its territory (and of those living abroad), as well as to ensure the sense of security (optimizing the satisfaction level). In this context, when defining the efficiency of public spending, we first and foremost refer to the standards of living of our citizens both in economic terms and in terms of satisfying the basic social needs and ensuring security (Barro, 1996: 29). Considering the top-down solutions such as the indicator suggested by OECD or other commonly applied quality-of-life indicators, and bearing in mind that these are very synthetic, highly generalised aggregates, a question presents itself of how to reach the due level of accuracy of analysis, when moving from the category of spending, which is defined in respective classification items, and how to refer to 
those aggregates? In this context, a number of instruments are available to evaluate the quality of respective spending items in the mid- and long-term, including performance budget (EC, 2002: 45), which, in the past several decades, has been the object of many publications, numerous studies and expert evaluations, as well as many discussions, monographs and polemics.

At the same time, a question arises, to which OECD is trying to find an answer, by conducting in 2016 another analytical and comparative study: is the performancebased budget and its other equivalents in respective countries of the world still being developed or not. In this context, it is worth looking at Polish experiences to check whether this tool is applied in Poland. Without getting too much into details, though respective stages related to performance budget may be considered successful, one can say that central-level performance budget has been developing dynamically in Poland since 2006 when the Polish government decided to implement it (Postuła, 2012: 68). An assumption was made that Poland's accession to the European Union was a good time to change the instruments of efficient management and to join the trend of modern management of EU funds which - in line with the standards set out by the European Commission - are accounted for in an innovative manner referred to as performance-based. This means that specific spending items have a clearly defined use for which they can be spent, the purposes they are meant to achieve, the milestones (work schedule - often a multiannual one), with the achievement of both impact and output indicators (and thus the achievement of objectives) contributing to the possibility of spending and accounting for the money.

Though the performance-based budget is a tool used by many countries worldwide, it is actually difficult to find a clear definition of what it is, both in the scientific nomenclature and in international studies (Robinson, 2013: 14). However, we can assume that the term "performance budget/planning" means, simply put, an institution consisting in planning the state budget expenditures by referring them to relevant tasks and sub-tasks, objectives and metrics (Jong, 2016: 4). It is a cuttingedge method of managing public funds by objectives that are adequately concretized and prioritized to achieve specific results, i.e. to complete tasks measured by a defined system of metrics.

State expenditure planning with the use of performance budget helps obtain answers to the following questions:

1. What tasks are executed by respective holders of budget parts in the state budget?

2. What expenditure does the state earmark to respective tasks?

3. What objectives are to be achieved by earmarking expenditure for specific tasks? 
4. What effects (results) are to be achieved by the accomplishment of the intended objectives?

5. To what degree have the intended objectives been achieved thanks to the expenditure undertaken?

Answers to these questions are hard to obtain using the traditional state expenditure planning.

Performance budget is an institution that has been applied and proved effective in the practice of many countries (among which the United States and New Zealand), including European Union member states (e.g. the United Kingdom, The Netherlands, France, Germany, Slovakia). Poland is clearly drawing on those solutions and experiences (e.g. France) (Postuła, 2011: 68). Some CEE countries, as of today, declare to have a performance budget in place, while it only means they have a defined catalog of budget classification, including a division of tasks, but it's hard to say they literally have a full-scale performance budget (Ruśkowski, 2011: $84)$.

Performance budget also has other advantages, namely:

- It is based on multiannual performance planning and ensures integration of multiannual financial plans with the state's formal strategies, thus drawing on financial planning methods in place in the European Community (e.g. New Financial Perspective 2007-2013, multiannual financial framework, annual budget of the European Communities), and it enables implementing the Lisbon Strategy and updating the Convergence Programme;

- It enables consolidating the public expenditure incurred both from the state budget and from other sources (e.g. EU funds, national special purpose funds);

- It enables planning public expenditure relating to the implementation of inter-ministry performance programs;

- It makes it easier to maintain a low budget deficit, which represents one of the requirements for meeting convergence criteria;

- It increases and broadens the transparency of public finance, in particular, it ensures full disclosure of the intended and actual use of public funds in the form of budget expenditure and expenditure financed from state specialpurpose funds and from EU funds;

- It increases the transparency of the public spending recognized in the budget law;

- It enforces budgetary control over what is important for the efficiency of public spending; 
- It enforces strict public finance discipline as regards the implementation of the budget law and the implementation of public finance entities' financial plans;

- It supports the process of good governance of public funds, which represents the fundamental principle of finance in the European Union.

\section{Solutions Used in Polish Work on Performance Budget}

In Poland, the first attempts at introducing performance budget were taken by local government entities (among others Kraków, Lublin, Szczecin, and Poznań in the 1990s). Meanwhile, at the central level, the process of introducing performance budget was initiated in 2006 at the Chancellery of the Prime Minister, where the first methodology of performance budget was developed, and the model of performance budget was prepared for some budget parts (i.e. for part 28 - Science and part 38 - Higher education). The areas and entities covered as well as the performance budget methodology were systematically broadened and improved as part of the implementation process, which has been coordinated by the Ministry of Finance since 2008.

It has been assumed that the objective of phase I of the work would be to implement a budget referred to as presentation or performance budget (according to the threelevel OECD classification, it is level one). In this model, the expenditure structure is presented based on performance, usually as a supporting document for legally binding acts, which helps increase the transparency of public spending and improve the quality of the debate on the state-wide spending policy. At the same time, efficiency information can be used, as an aid, in managing public finance as the information and management functions complement each other. Meanwhile, at further implementation stages, efficiency information is expected to be developed towards the so-called performance-informed budgeting, which enables direct support for allocation decisions taken as part of the budget process and mid-term planning (Marcel, 2012: 34).

Assumptions as to objectives and as to major stages of performance budget implementation are reflected in the adopted legislative solutions, introduced with the Act of 27 August 2009, on Public Finance, and Act of 27 August 2009 - Implementing measures to Act on Public Finance, and then specified in greater detail in the implementing measures (Postuła, 2009: 84). The Law on Public Finance defines the concept of the so-called "performance-based" presentation while specifying the place, role, scope (in terms of areas and entities) of performance budget in the public finance system. Meanwhile, relevant regulations 
of the Minister of Finance define the methodology of performance-based budget planning, performance-based budgetary reporting and the principles of performance-based budget implementation recording (Stankiewicz, 2010: 45). It should be emphasized that the provisions of the Law on Public Finance, which regulate respective elements of performance budget system, became effective gradually, as per time schedule provided for in the implementing measures. The last ones to take effect, as of 1 January 2013, were the legal provisions relating to the assessment of public spending efficiency and effectiveness, which regulate the overall control of the Minister of Finance as regards efficiency and effectiveness of performance budget implementation as well as supervision and control of holders of respective budget parts over efficient and effective implementation of performance plans based on objective achievement metrics (Owsiak, 2011: 68). Hence, the first budget year which saw a full application of performance budget mechanisms planning (including consolidated ones), recording, reporting as well as control and supervision mechanisms - was 2013.

The adopted work schedule for performance budget implementation process enabled a gradual improvement of the solutions adopted, taking account of suggestions and recommendations formulated both by budget holders directly engaged in the process and by the Supreme Audit Office (O'Keefe, Simunic, Stein, 1994: 67). Particularly significant recommendations were also formulated in final reports from two far-reaching reviews conducted by OECD experts (Performance Budgeting in Poland. An OECD Review of 2011 and Public Governance Review (OECD, 2011: 26). Poland. Implementing strategic-state capability of 2013), where high appreciation was expressed for what had been achieved so far in the area of performance budgeting. The actions undertaken were oriented to increase transparency, cohesion, quality, usability, and comparability of data on public spending efficiency and effectiveness, as acquired through performance budget.

When joining the European Union in 2004, Poland was aware that transfers received from that community would bring great benefit to the Polish economy. In addition, they also contributed a new model of public spending, the so-called management of European funds by objectives (Orłowski, 2010: 124). Therefore, this spurred reflection on whether to apply similar principles of spending to all expenditures of the public sector in Poland and marked the beginning of official work on implementing performance budgeting in the government administration.

The principal factors that were necessary for Poland when taking the decision to implement performance budgeting included:

- Support from Parliament and government for the performance budget implementation process; 
- Building a team with the strong determination to carry out the necessary reforms;

- Financial resources necessary to prepare public administration employees and decision-makers for the implementation and use of performance budgeting.

If public funds are spent, they should be earmarked for specific tasks which need to be completed, and concrete results of the completion of those tasks are anticipated (Cohen, 2008: 88). If the expected results are not met, then it must be examined why this happened and conclusions must be drawn for the future - this is the proper spending management. Such an assumption was most correct. One fundamental error was committed, however. The term "performance budget", as is well known, corresponds, first and foremost, only to a selected strictly "financial" aspect of public sector functioning. Indeed, the budget is associated exclusively with financial funds and refers neither to the efficiency of operations, nor to the results achieved, and it is directly handled by financial services.

Such positioning of work on performance planning can be seen as the source of trouble with understanding the appropriate function of the reform being undertaken. If we compare the public finance sector to the private sector, in the private sector the preparation of strategic documents, their evaluation and drawing conclusions from this process are the responsibility of specially appointed business units, directly reporting to a Management Board Member. Financial departments take part in such a process, but without the leading role as to the shape of the whole document. To a great extent, such rule should be reflected in the public sector. However, a decision was made to delegate the process of management by objectives in the public sector directly to budgetary units rather than strategic ones. This was one of the greatest ailments in the first years of performance budget implementation in Poland.

The accounts of those taking part in the first Polish experiences, where performance budget was first applied at the local level (it was in the city of Kraków) show that the assumptions were similar already from the beginning (Marczewski, 2012: 21). Those responsible for performance budget implementation at the government administration level did not opt to change the name, despite this concern. This, unfortunately, caused a shift in the emphasis of this budgeting method towards a budget that is associated solely with a breakdown of money intended to perform tasks. This imperfection, initiated in the beginning, was repeated when the process of budget implementation in the government administration sector started, when the responsibility for the functioning of this tool was placed, first and foremost, on budgetary units, which, obviously, went beyond the specifics of their work. Of course, throughout the period of performance budget implementation in Poland, which involved a great number of seminars and expert opinions, there were attempts to convince competent units at ministries, central offices and agencies, 
that performance budget is a tool formulated to enable them to use it in the decision-making process rather than only for the financial and accounting purposes (Mielcarz, 2012: 60). Undoubtedly, this had also its advantages as, in many cases, those coordinating and taking an active part in budget negotiations, and those managing those units had a chance to get a deeper understanding of the essence of the matter for which funding was provided, while, previously, the amounts of that funding had been planned primarily based on historical trends and data. Better efforts were made to understand the use of funds for which demand was reported, if, in parallel, a consideration was given to the objectives and metrics of respective budget tasks. However, ultimately this could not replace the expertise input of line units competent for the control, supervision, and evaluation of respective public tasks, as well as for strategic planning in those areas (Franek, 2010: 6). Admittedly, this way of involving competent units, for example, those at ministries, came later at a mass scale, but ultimately it has come to be quite a widespread, unquestionable, thorough, systematic and reliable practice of the holders of all budget parts.

First and foremost, efforts were made to increase the degree of integration of performance budget with the development policy, and the degree of integration of internal management systems and instruments with the performance budget. To combine responsibility for public finance management (as resulting from the Public Finance Law) with responsibility for initiating, formulating, as well as implementing and coordinating Council of Ministers policy (as defined in the Law on Government Administration Divisions), while maintaining the constitutional or statutory independence of respective supreme public authorities and audit, judiciary and security institutions, was the aim of detailed changes regarding the principles of laying down the performance structure (that of budgetary tasks, subtasks and measures), defining objectives or identifying the measures of their completion. Work on fine-tuning the system for measuring the degree of completion of objectives defined as part of performance budget (system of metrics) was another major element in this respect. In order to improve the quality of the measurement system, starting from the planning process for 2013, a procedure was introduced whereby the Minister of Finance would assess, ex-ante, the completion and compliance of metrics for a given budgetary year with standards and methodological guidelines.

Secondly, with an aim to satisfy information and analytics needs related to the assessment of public spending efficiency and effectiveness in the context of the possibility of using efficiency information in support of allocation decisions, efforts were also made to connect both classification perspectives of budget planning (performance-based and traditional one) - by integrating financials at the level of "budgetary task - division and chapter of budget classification", and to ensure stricter correlation between planning results and expenditures, and thus the budget 
holders' accountability - for example by introducing a principle that at the stage of preparing materials for the Multiannual State Financial Plan, objectives and metrics for budgetary tasks and subtasks are defined, and the values of metrics are adapted to full compliance with the level of budgetary allocation of funds in accordance with the budget law for a given year.

Thirdly, work was also undertaken to ensure the necessary assistance, and integration of IT processes supporting performance-based budgetary reporting and planning at the Trezor platform. Ultimately, these processes should enable the integration of all budgetary processes into one IT system.

A fourth area involved training activities, which were strictly entwined with the adopted further stages of the implementation process. Initially, they focused on the aspects relating to performance budget concept and methodology. However, as time went by, the increasingly greater emphasis was placed on the development of knowledge, skills, and attitudes which make it possible to use data from the presentational model of performance budget to manage units and assess the public spending efficiency and effectiveness and to monitor and evaluate public tasks.

Table 1 features the main stages of work on performance budget implementation in Poland, as presented by the Ministry of Finance.

\section{Table 1 Information on Main Stages of Work on Performance Budget Implementation in Poland}

\begin{tabular}{|c|c|c|}
\hline Period & Legal solutions & Expected result (products) \\
\hline $2006-2007^{*}$ & $\begin{array}{l}\text { 2006: the following duties introduced in the Public } \\
\text { Finance Law: } \\
\text { Budget holders' duty to provide a performance- } \\
\text { based presentation of expenditure in the explanatory } \\
\text { memorandum for the budget bill } \\
\text { Council of Minister's duty to present task performance } \\
\text { information to the lower house of Polish Parliament } \\
\text { (Sejm) as part of the reports on the implementation of } \\
\text { the state budget }\end{array}$ & $\begin{array}{l}\text { Explanatory memorandum for the } 2007 \text { budget bill } \\
\text { - performance budget model for } 2 \text { budget parts, i.e. } \\
\text { part } 28 \text { - Science and part } 38 \text { - Higher Education } \\
\text { Explanatory memorandum for the } 2008 \text { budget bill } \\
\text { - expenditure of } 67 \text { budget holders, recognized } \\
\text { in } 82 \text { budget parts, broken down into tasks and } \\
\text { subtasks }\end{array}$ \\
\hline 2008-2010 & $\begin{array}{l}\text { 2009: new Public Finance Law adopted: } \\
\text { Performance-based presentation defined } \\
\text { A duty introduced to present a performance-based } \\
\text { consolidated expenditure plan (inclusive of state } \\
\text { budgetary units, state special-purpose funds, executive } \\
\text { agencies, state legal persons and public finance } \\
\text { institutions ( } p l . \text { instytucje gospodarki budżetowej) in the } \\
\text { explanatory memorandum for the budget bill } \\
\text { A duty introduced to provide a performance-based } \\
\text { presentation of the information on expenditure } \\
\text { implementation, in reports on the implementation of the } \\
\text { state budget } \\
\text { A duty introduced to provide a performance-based } \\
\text { presentation of multiannual programs in the budget law } \\
\text { Delegations for the Minister of Finance to define } \\
\text { by regulations: the performance-based planning } \\
\text { methodology, performance-based budgetary } \\
\text { reporting, and principles performance-based budget } \\
\text { implementation recording. }\end{array}$ & $\begin{array}{l}\text { Performance-based explanatory memoranda } \\
\text { for the budget law - for respective years (from } \\
\text { the explanatory memorandum for } 2013 \text { onwards, } \\
\text { these have been prepared as a consolidated } \\
\text { presentation) } \\
\text { Performance-based information on the } \\
\text { implementation of expenditure in respective years. } \\
\text { Performance-based budgetary planning } \\
\text { methodology set out annually in a regulation of the } \\
\text { MoF on detailed method, procedure, and deadlines } \\
\text { for developing materials for the budget bill. }\end{array}$ \\
\hline
\end{tabular}




\begin{tabular}{|c|c|c|}
\hline Since 2010 & $\begin{array}{l}\text { 2012: entry into force of the duties as regards } \\
\text { performance-based budget reporting and performance- } \\
\text { based budget implementation recording } \\
2013 \text { : entry into force of legislation as regards: } \\
\text { Overall MoF's control over the efficiency and } \\
\text { effectiveness of performance-based budget } \\
\text { implementation } \\
\text { Supervision and control by holders of respective } \\
\text { budget parts as regards efficiency and effectiveness of } \\
\text { the implementation of performance-based plans based } \\
\text { on objective completion metrics } \\
\text { Methodological efforts focused on, among other things: } \\
\text { Linking performance-based budgetary planning with } \\
\text { strategic planning and with the Law on Government } \\
\text { Administration Divisions (objectives set by competent } \\
\text { ministers at the task level) } \\
\text { fine-tuning the performance-based expenditure } \\
\text { classification - by linking it with the Law on } \\
\text { Government Administration Divisions and the } \\
\text { traditional budget classification (at the level "task- } \\
\text { division/chapter") } \\
\text { fine-tuning the metrics system (among others, thanks to } \\
\text { the procedure of their prior vetting by MoF, introduced } \\
\text { from planning for } 2013 \text { onwards) } \\
\text { linking performance-budget system with budget } \\
\text { holders' other management systems }\end{array}$ & $\begin{array}{l}\text { Performance-based explanatory memoranda } \\
\text { for budget bills - for respective years (from the } \\
\text { explanatory memorandum for } 2013 \text { onwards, } \\
\text { these have been prepared also as a consolidated } \\
\text { presentation) } \\
\text { Performance-based information on the } \\
\text { implementation of expenditure in respective years. } \\
\text { Performance-based summary semi-annual reports } \\
\text { on the implementation of expenditure from the } \\
\text { state budget and EU budget and financial plans of } \\
\text { state special-purpose funds, executive agencies, } \\
\text { state legal persons and public finance institutions. } \\
\text { Performance-based budgetary planning } \\
\text { methodology set out annually in a regulation of the } \\
\text { MoF on detailed method, procedure, and deadlines } \\
\text { for developing materials for the budget bill. }\end{array}$ \\
\hline
\end{tabular}

* In 2008, the responsibility for the process of performance budget implementation was taken over by the Ministry of Finance.

Source: Own elaboration based on data provided by the Ministry of Finance.

Taking account of the complex and multi-aspect nature of performance budgeting introduction as part of which it was necessary to work out and then implement legal, systemic and technical solutions regarding planning, accounting, reporting as well as supervision and control over efficiency and effectiveness with the involvement of budget holders of all levels, external experts, and the necessary resources, it was decided that this process would be divided into several phases over many years, using the financial support from EU funds. To that end, two system projects were pursued, co-funded by the European Social Fund, as part of Operational Programme Human Capital, Priority 5 Good Governance, Measure 5.1 Enhancing the capacity of the government administration, Sub-measure 5.1.2 Implementing performancebased finance management system. Apart from the above-mentioned systemic measures, the projects also provided for training, information and promotional measures to support the institutional, analytical and competitive capacity of budget holders, and for preparing the employees in question adequately for fulfilling the new tasks. Indeed, ensuring that the employees involved in the process have the skills, motivation, and awareness of the significance of the changes being introduced is one of the key success factors. 


\section{Successes and Failures of Implementation Efforts}

What was the first success of the Polish work on performance budget, or the first product of the budget implementation process? These were elements already included in the explanatory memorandum for the 2008 budget bill; namely, the document contained information on performance budget for two budget parts, i.e. 28. Science and 38. Higher education. This was no random choice since, as mentioned before, immense knowledge was undoubtedly needed to carry out the whole process; knowledge and experts assisting budget holders at given ministries in preparing the explanatory memorandum for the budget law from a performancebased perspective.

In 2006, attempts were made to implement performance-based budget not only at the Ministry of Science and Higher Education. Such an attempt was made also at the Ministry of Agriculture and Rural Development, and at the Ministry of Health, but it failed, at least when it comes to the 2007 budget law. However, this was not time wasted as appropriate conclusions were drawn from the experiences of those two ministries, including the identified risks that arose and materialized in this case at those ministries. These conclusions served to prepare, the next year, that is in 2007, a performance-based explanatory memorandum for the budgetary legislation for 2008, for as many as sixty-seven budget holders, and these expenditures were recognized in eighty-two parts. Tasks and subtasks were identified as part of this spending envelope. This undoubtedly required huge amount of work, including work on building the awareness of performance budget advantages, as well as discussions and arguments that the implementation of that tool would bring indisputable benefits to each budget holder.

As often mentioned in international reports, it is of great importance to reach the adequate decision-making level to support this process. For Poland, such position was the Secretary of State at the Chancellery of the Prime Minister, who was directly responsible for the performance budget implementation process and performed all operations involved in the process. Once performance budget implementation was moved to the Ministry of Finance, the National Coordinator for Performance Budget was the equivalent of that position. At the time the first results were obtained, as reflected in the explanatory memorandum for the budget law for 2008, several other elements were also noticed and it was understood that time is needed to implement the provisions in the Public Finance Law to fully implement this tool (Jong, Hardt, 2012: 16). Consequently, as part of the ongoing work on a brand new Public Finance Law, a few new regulations were implemented and proposed to fully describe performance budget in terms of its structure, scope, responsibility, evaluation. This was one of the best ideas on how to sanction the whole process, and to convince 
those still in doubt that the performance budget implementation process would not end with a pilot project, or with the presentational aspect, but it would have further consequences in the coming years, and thus one should prepare for it in a proper and systemic manner.

Another success in performance budget implementation is having included, as one of the appendices to the budget law itself, a performance-based breakdown of multiannual programs. In 2010, a performance-based breakdown of multiannual programs was compiled for the first time, which was presented in the 2011 budget law. Indeed, in accordance with Art. 102 of the Law of 27 August 2009 - Implementing measures for the Public Finance Law, investment projects that are recognized in the breakdown of multiannual investment projects enclosed as appendix to the 2010 budget law, and whose completion date is set after 31 December 2010, became multiannual programs as of 1 January 2011.

Another thing that can be called a major success is having developed and implemented an application program making it easier to prepare performancebased materials for the budget law. Initially, this program was called BUZA. It was commissioned by the Minister of Finance and contained the currently applicable principles of performance budget preparation. It was also adapted to the fact that budget holders came from three different levels. As time went by and as performance-budgeting developed in Poland, an attempt was made to make the application program compatible with the IT system whose operation is still a work in progress. As part of that work, a program extension was developed for the Trezor IT system used for state budget management. This way, the Minister of Finance aims to ensure, in future, the integrality of both budgetary systems.

However, performance budget in Poland has not been all success - a few failures that happened can also be indicated. Probably one of the biggest ones was to include the performance budget in the explanatory memorandum to the budget bill. Even though performance budget elements are contained in the law itself, performancebased state expenditures are still presented in the explanatory memorandum for the bill.

Another thing that can be indicated as a failure is a lack of the link and of the full integration of the traditional budget with the performance budget. Though many regulations have already introduced performance budget to the daily practice of the holders of budget parts, full awareness and integration of those budgets have not yet been achieved. Nevertheless, looking back, it can be concluded that an IT system that takes account of both budgetary systems would solve many problems faced by budget holders. 


\section{Performance Budget Implementation in Poland - Sources of Funding for Project}

Performance budget preparation and implementation required large financial outlays, as evidenced by many international experiences. Out of concern for the condition of public finance in Poland, co-funding from EU funds for this task was envisaged. The costs of the reform relating to performance budget implementation were estimated in 2006 by the Chancellery of the Prime Minister at the time Operational Programmes were being prepared and negotiated with the European Commission. Operational Programmes were approved by the decision of the European Commission. An action plan for the years 2007-2008 was prepared for parts of Sub-measure 5.1.2 "Implementing performance-based finance management system" to be implemented as part of Measure 5.1 "Enhancing the capacity of the government administration" of the Operational Program Human Capital, Priority 5 of OP HC, approved on 5 December 2007 by the OP HC Managing authority, acting pursuant to a recommendation from the OP HC Monitoring Committee included in the resolution no. 4 of the Monitoring Committee of 21 November 2007.

When embarking on measures related to performance budget implementation in 2008, it was planned that all of first- and second-level budget holders and $5 \%$ of those at the third level would receive support in their work on preparing a performance-based budget. Work was completed on laying down the terms of cooperation between the Intermediate Body (Chancellery of the Prime Minister) and the Beneficiary (Ministry of Finance) on implementing system projects as part of Measure 5.1 "Enhancing the capacity of the government administration" of the Operational Programs Human Capital - a memorandum of understanding was signed between General Directors of both institutions.

The Action Plan envisaged that projects worth, in total, ca. PLN 234,137,000 would be implemented in the years 2008-2015, including "Support for performance budget preparation and implementation at the central level" (worth, in total, ca. PLN 70,488,000); "Staffing and technical support for main budget holders in the process of performance budget implementation" (worth ca. PLN 83,258,000) and "Performance budget implementation by all budget holders" (worth ca. PLN $80,391,000)$.

As part of the first project, "Support for performance budget preparation and implementation at the central level", measures funded in 2008 included remuneration for professional and support staff at the Ministry of Finance salaries and performance allowances, 40.5 people in total; 19 work stations were equipped for the purposes of work on performance budget and implementation of EU projects; training was held for MoF staff; an international conference promoting 
performance budget was organized; expert opinions and analyses were prepared, for example, on the applicable legal regulations in force, to identify the regulations that need to be amended in order to implement multiannual performance planning; on international experiences with the implementation and development of annual and mid-term planning and multiannual performance planning; on monitoring and evaluation of budget implementation as regards priority tasks ("efficiency audit"), on design assumptions for the IT System to support an efficient public finance management using the tools created by performance budget.

As part of "Staffing and technical support for main budget holders in the process of performance budget implementation in the years 2009-2015", staffing support was provided, further workstations were equipped and many training courses for main budget holders were held.

As part of the third project, "Performance budget implementation by all budget holders", 2008 saw activities such as methodology training on performance budgeting, multiannual and strategic planning for employees of selected secondand third-level budget holders; further expert opinions were prepared: as regards the definition of priority tasks, implementation of an indicator-based system for monitoring and evaluation of top-priority public tasks.

\section{Conclusions}

The future of performance budget in Poland remains an open-ended issue, while the present debates and discussions, as well as actions and decisions, often call into question even the fundamental foundations of the work to date, in the search of new, more optimum solutions. It's worth emphasizing that many major issues related to performance budgeting are also regularly called into question in OECD countries. There is a constant quest for the best methodological solutions to maximize usability and increase the functionality of this tool in public finance systems of respective nation states. OECD is conducting comparative research (survey) consisting of running questionnaires to analyze the practical application of this tool worldwide. Research and analytical activities in this respect are also being performed by the European Commission, as evidenced by the last conference dedicated to the performance budgeting method (among others, for the purposes of European Commission's budget planning) held in the first half of 2016.

Since 2016, the current Polish government has been announcing a budget system reform, starting from the budget planning process for 2018. However, the discussion of this reform mostly focuses on spending reviews, giving less and less attention to performance budget. When structuring the 2017 budget, performance budget 
still remains a presentation instrument, sometimes discussed at the Parliament (mostly at the sessions of Sejm committees), and some other times at the Council of Ministers level.

There was one more method that could have undoubtedly streamlined the performance budget implementation in Poland. It could have happened at the time the first results, i.e. the ability to define objectives, were being implemented and accomplished. What should have been done back then is the instruments already functioning in Poland, used by the administration of various levels to increase or assess the public spending efficiency, should have been reviewed. Indeed, few people realize that such tools were functioning, let alone on what principles this was done. For example, not many citizens know that the state subsidizes inter-voivodship train transport, in some voivodships, with amounts in the order of PLN $580 \mathrm{M}$ a year, and even fewer people are aware that the carrier who receives that money must meet specific punctuality and safety indicators as well as many others. If it fails to, it is liable to a penalty. Therefore, it's a typical mechanism of management by results or management by objectives - meaning that we pay for a service, but if a service is of a lesser quality, the service provider pays a penalty. This is a classical element that is in place in the private sector. However, it turns out that it is also in place in the Polish public sector, and this is but one of many examples. Consequently, the element that was overlooked when implementing performance budgeting in Poland was to identify such solutions that already function, and integrate them with performance budget, or at least, indicate to the administration that such mechanisms exist and work very well. This would have been, undoubtedly, a good spur for full implementation of an integrated and compatible system for the efficiency assessment (public spending evaluation). Indeed, if we have performance tools enabling management by objectives, in some areas, then, undoubtedly, they could be also implemented in further spheres of state functioning.

Another aspect of such an approach would be to intensify practices vying for the limited public funds based on the operating results achieved. A textbook example of that would be the United Kingdom introducing, in early 1980s, a model of selective scientific research funding, the role of this system being not only to allocate resources, but also to impact the efficiency as a means of communication (for signaling needs and expectations) between the providers of funds, higher education institutions and those being educated (Owsiak, 2008: 66).

The implementation of the above solutions could, obviously, involve developing a set of standards for public services (and development of benchmarks for their provision) that could be negotiated and mutually worked out during public debates (including public consultations on the budget), evaluating the level at which those standards are met, and, consequently, strengthening the function of social choice 
towards optimization of goods provided by the state (which are, in many countries, presented in the so called citizens charts - a set of guidelines on civic society's expectations on how the administration should deliver public tasks).

In consequence, the implementation streamlines the management process, thus increasing the efficiency of resource allocation. Considering that, on the local level, there exists more direct communication with the community of a local administrative division, the message sent by the latter to its citizens (voters) on the efficiency of its operations, is more clear. If it doesn't efficiently manage its funds, political opponents will be quick to notice it - in the coming elections. Consequently, in those administrative divisions, much more often than at the central level, management is by objectives and by result planning, even though it's not expressly referred to as performance budget. Therefore, it would probably suffice to create some legal instruments to sanction it both at central and local level. It is necessary, then, to introduce responsibility for the results achieved, and for the objectives achieved, and a method to ensure relevant mid- and long-term accountability. It is also important to make the bonus and reward system dependent on the results achieved, while not fully relying on its functioning, considering the objectively inevitable risks that can materialize (e.g. risk of results being manipulated, external circumstances of the activities undertaken etc.).

This is also corroborated by OECD research. One of the basic problems faced by the public sector is to attract highly skilled individuals with leadership skills to accept the challenge of managing an immense scale of public funds, and of implementing public tasks. Public sector managers cannot be given a simple objective that is measured by a profitability ratio. For public sector managers, profit means having achieved a higher citizen's satisfaction level and having improved quality of life and sense of security indicators, depending on the sphere in which we operate. Consequently, these objectives are still a challenge. Of course, the question remains of how to evaluate, on the performance basis, the efficiency of respective expenditures, or the efficiency of investment projects, which shall be discussed in detail further in the paper.

\section{References}

Barro, R.: Determinants of Economic Growth: A Cross-Country Empirical Study, National Bureau of Economic Research, NBER Working Paper no. 5698 (1996).

Central Expenditure Evaluation Unit, Department of Public Expenditure and Reform. www. publicspendingcode.per.gov.ie.

Cohen, J.R.: The Corporate Governance Mosaic and Financial Reporting Quality, Journal of Accounting Literature no.1 (2008). 
De Jong, M.: Performance-Based Budgeting: Lessons from Academic Research and Practices in the Public Sector, 2016. www.ec.europa.eu.

DG ECFIN, Thematic Review on the Quality of Public Expenditure. Preparing and Implementing Spending Reviews, Brussel, 2014.

Evaluating EU Activities. A Practical Guide for the Commission Services, Directorate-General for the Budget, European Communities, Brussels: European Commission, 2004.

Franek, S.: Reguły fiskalne w przemianach instytucjonalnych finansów publicznych (Fiscal rules in the institutional changes of public finances), Zeszyty Naukowe Uniwersytetu Szczecińskiego (Scientific Papers of the University of Szczecin) no. 3 (2010).

Kołodko, G.: Nowy pragmatyzm, czyli ekonomia i polityka dla przyszłości (A new pragmatism, i.e. economy and politics for the future), in: Pach, J., Kowalska, K., Szyja, P. (eds.): Ekonomia umiaru. Realna perspektywa? Nowy paraygmat Grzegorza W. Kołodko (Economics of moderation. The real perspective? A new paradigm of Grzegorz W. Kolodko), Warszawa: PWN, 2016.

Marcel, M.: Budgeting for Fiscal Space and Government Performance Beyond the Great Recession, Paris: OECD, 2012.

Marczewski, K.: Budżet zadaniowy a cele polityki gospodarczej w Polsce (Performance budget and economic policy goals in Poland), in: Albiński, P. (ed.), Budżetowanie zadaniowe w kontekście sanacji finansów publicznych w krajach Unii Europejskiej (Performance budget in the context of public finance restructuring in the European Union countries), Warszawa: Szkoła Główna Handlowa, 2012.

Mielcarz, A.: Modernizacja budżetowania zadaniowego (GPRAMA) jako działania podejmowane przez administrację prezydenta B. Obamy w celu racjonalizacji finansów publicznych w Stanach Zjednoczonych (Modernization of performance budget (GPRAMA) as activities undertaken by the administration of President B. Obama in order to rationalize public finances in the United States), in: Woźniak, B., Postuła, M. (eds.): Budżet zadaniowy metodą racjonalizacji wydatków (Performance budget based on the rationalization method), Warszawa: CeDeWu, 2012.

Moździerz, A.: Strengthening the Post-crisis Fiscal Rules - the Case of Spain, Slovakia, and Sweden, Equilibrium, Quarterly Journal of Economics and Economic Policy no. 2 (2015)

O'Keefe, T.B., Simunic, D., Stein, M.: The Production of Audit Services: Evidence from a Major Public Accounting Firm, Journal of Accounting Research no. 2 (1994).

Orłowski, W.: Ewaluacja - instrument refleksyjnego zarządzania państwem (Evaluation - the instrument of reflective state management), in: Szałaj, A. (ed.): Ewaluacja w strategicznym zarządzaniu publicznym (Evaluation in strategic public management), Warszawa: PARP, 2010.

Owsiak, S.: (ed.), Nowe zarządzanie finansami publicznymi w warunkach kryzysu (New public finance management in crisis conditions), Warszawa: PWE, 2011.

Postuła, M.: Rola ewaluacji w budżetowaniu zadaniowym (The role of evaluation in performance budget), in: Haber, A. Szałaj, M. (ed.): Ewaluacja wobec wyzwań stojących przed sektorem 
finansów publicznych (Evaluation of the challenges facing the public finance sector), Warszawa: PARP, 2009.

Postuła, M.: Budżet zadaniowy w Polsce - osiągnięcia i wyzwania na przyszłość (Performance budget in Poland - achievements and challenges for the future), in: Ruśkowski, E. (ed.): Instrumenty nowego zarządzania finansami publicznymi w wybranych krajach Unii Europejskiej (Instruments of new public finance management in selected European Union countries), Bialystok: Temida 2, 2011.

Postuła, M.: Racjonalizacja wydatków publicznych a podstawowe funkcje państwa (Rationalization of public expenditure and basic state functions), Warszawa: Wydawnictwo SGGW, 2012.

Public finance in EMU 2002, European Commission, Directorate-General for Economic and Financial Affairs, European Economy no. 3 (2002).

Public Service Reform Plan 2014-2016, 2016. www.reformplan.per.gov.ie.

Robinson, M.: Spending Reviews, Paris: OECD, 2013.

Ruśkowski, E. (ed.), Instrumenty nowego zarządzania finansami publicznymi w wybranych krajach Unii Europejskiej (Instruments of new public finance management in selected European Union countries), Bialystok: Temida 2, 2011.

Shick, S.: Budgeting for Fiscal Space, 2014. www.oecd.org.

Spending Review, HM Treasury, 2010. www.gov.uk.

Spending Review: Objectives, Design \& Processes, World Bank Seminar, Warszawa: Ministerstwo Finansów, 2014.

Stankiewicz, J.: Problemy racjonalizacji wydatków publicznych i wieloletniego planowania finansowego w aspekcie budżetu zadaniowego i wieloletnich planów finansowych w Polsce (Problems of rationalization of public expenditure and long-term financial planning in the aspect of perfomance budget and long-term financial plans in Poland), in: Ruśkowski, E. (ed.): System prawa finansowego (System of financial law), Warszawa: Wolters Kluwer, 2010.

Woźniak, B., Postuła, M.: Budżet zadaniowy metodą racjonalizacji wydatków, CeDeWu, Warszawa, 2012.

European Fund for Strategic Investments in 2016, 2016. www.eib.org.

PL: Act of 27 August, on Public Finance, as amended.

PL: Act of 27 August 2009 - Implementing measures to the Act on Public Finance. 